\title{
The Measurements of Tourist Satisfaction Levels on Attractions, Accessibility, and Amenities in Pulesari Tourism Village, Sleman Regency
}

\author{
M. Dzulkifli ${ }^{1}$, J. M. Masjhoer ${ }^{2}$ \\ Affiliation \\ ${ }^{1}$ Politeknik Negeri Jember; ${ }^{2}$ Sekolah Tinggi Pariwisata Ambarrukmo
}

\section{Correspondence}

M. Dzulkifli. Politeknik Negeri Jember. Lingkungan Panji, Tegalgede, Sumbersari, Jember Regency, East Java 68124. Email: dzulkifli@polije.ac.id

J. M. Masjhoer. Sekolah Tinggi Pariwisata Ambarrukmo. Jl. Ringroad Timur No.52, Pelem Mulong, Banguntapan, Kec. Banguntapan, Bantul, Daerah Istimewa Yogyakarta 55198.

Email: jussacmaulana@stipram.ac.id

\begin{abstract}
This study aimed to determine the level of tourist satisfaction and the performance of attractions, accessibilities, and amenities (3As) in Pulesari Tourism Village (PTV). This study uses both qualitative and quantitative (mixed method). The population in this study was tourists who visited PTV during the period of August to September 2018. A hundred samples were collected using Purposive Sampling method. Data were collected by distributing questionnaires, in-depth interviews, field observations, and documentation. Gradual quantitative-qualitative data analysis is used as a technique to analyse the data. It begins with Likert satisfaction analysis, Importance Performance Analysis, and qualitative descriptive analysis. The results showed that the level of tourist satisfaction was in the satisfied category. Managers need to improve the quality of attraction components and become a priority to meet tourist expectations. Based on this study, the results show that the quality of the 3 As component influences the level of satisfaction of visiting tourists. The three components become unity and support each other. A low assessment of one component can be improved by other components that are perceived to have better quality.
\end{abstract}

Keywords: Tourist satisfaction; Pulesari; Tourism village; Sleman.

Article Information

Submitted 10 November 2019 | Accepted 3 September 2020

Recommended Citation: Dzulkifli, M., Masjhoer, J. M. (2020). The Measurements of Tourist Satisfaction Levels on Attractions, Accessibility, and Amenities in Pulesari Tourism Village, Sleman Regency. Jurnal Pariwisata Terapan, 4(1), 48-58.

https://doi.org/10.22146/jpt.51330

Copyright (C) 2020 by the author(s). This article is published by Universitas Gadjah Mada, Indonesia unde the Creative Commons Attribution (CC BY 4.0) license. Anyone may reproduce, distribute, translate, and create derivative works of this article (for both commercial and noncommercial purposes), subject to ful attribution to the original publication and author(s). The full terms of this license may be seen at http://creativecommons.org/licenses/by/4.0/legalcod 


\section{Introduction}

Pulesari Tourism Village (PTV) or better known as Dewi Pule is one of the leading tourism villages which administratively located in Turi District, Sleman Regency. This tourism village has diverse tourism potential and complete supporting facilities. Various tourism attractions are offered to tourists such as outbound, river trekking, Jathilan arts, Kubro Siswo arts, and tour packages related to thorny palm. Since it was inaugurated as a tourism village by the Sleman Tourism and Culture Office in 2012, PTV continues to show a positive trend in the tourism sector. This can be seen from the increase in the number of tourist visits, the improvement of tourist facilities and infrastructure, the diversification of tourism products, and the communities who are almost entirely involved and affected by tourism activities. PTV is categorized as one of independent tourism villages with its income reached 4 billion rupiahs in 2018. Dewi Pule is also a model for sustainable tourism destination in Sleman which has been recognized by GSTC UNWTO and RECP programme in cooperating with UNIDO.

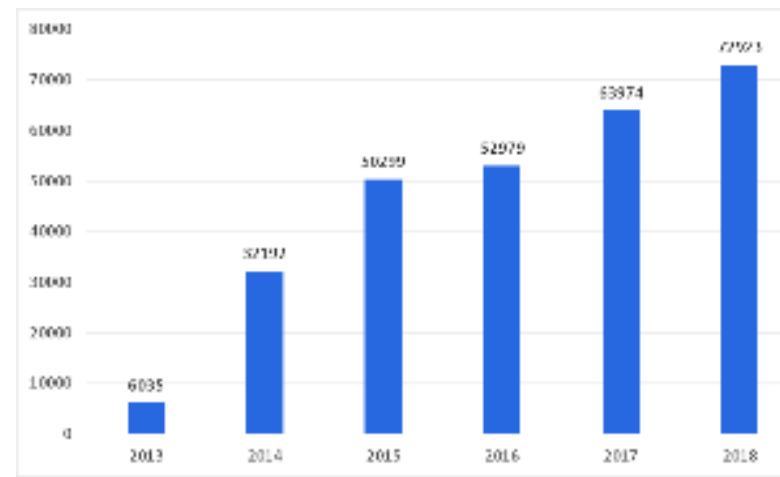

Figure 1. Number of tourist visitors in PTV from 2013 to 2018

(Source: Pulesari Tourism Village, 2019)

The increasing number of tourist visits in PTV is believed as the success of a tourism development that inseparable from the role of managers in forming the quality of tourism products, in this case is the tourism village or rural tourism. Middleton, et al (2009) and Suwantoro (1997) state that there are three main components of tourism products, namely attractions, accessibility, and amenities. In line with the statement, Nuryanti (1993) also emphasized that tourism villages are formed from the integration between attractions, accommodation and supporting facilities that are presented in a community life structure that is integrated with local wisdoms and traditions. The 3As (Attraction, Accessibility, and Amenities) in tourism is a product and it is considered as an important component in every tourism attraction and its quality must be continuously developed and maintained.

Tourists' satisfaction becomes a benchmark in improving the tourism products quality to increase visits and to form tourist loyalty. Broadly speaking, the satisfaction level means the stages of consumer reaction to the services provided by providers. There are two important variables namely expectations and performance. The level of satisfaction is based on a person's background or experience compared to the service performance obtained (Gonzales, et al, 2007; Kottler \& Keller, 2006; Sunarto, 2003).

Several studies related to tourist satisfaction in tourism destination attributes such as tourist attraction, tourist facilities, supporting infrastructure, services and attractions has been 
carried out by some researchers (Kozak \& Rimmington, 2000; Kozak, 2001; Nasution, et al, 2005; Oktaviani \& Suryana, 2016; Sulistiyana, 2015; Wang, 2016). According to Alegre and Garau (2010), overall satisfaction and interest in repeating to a tourist destination is determined by the rating of tourists on the destination attributes. The tourists' experience in a destination will determine the decision of tourists to visit again. Negative experiences may not affect the overall experience gained but will make the destination less attractive and thus reduce the possibility of a repeat visit. Most tourists have their own experiences in various destinations, and their perceptions would be influenced by comparing facilities, attractions, and service standards (Laws, 1995).

Some studies show that there is a positive correlation between the quality of tourism attributes and tourist satisfaction (Basiya \& Rozak 2012; Budiono, 2004; Bursan, 2006; Hermawan, 2017; Sulistiyani, 2010). Tourists will be encouraged to travel, stay longer, and increase their loyalty due to the quality of attractive attractions, complete facilities, supporting infrastructure, less traffic jam, and friendly residents which ultimately significant in tourism (Do Valle, et al. 2006; Kalebos, 2016; Taufiq, 2005). On the other hand, tourist satisfaction could be an effective means for promotion. Therefore, to forms positive perceptions of destination with various tourism attributes to tourists is one of the success keys to develop tourism destination (Bodlender, et al., 1991; Meng, Tepanon, Uysal, 2008).

The PTV management is run professionally by the local community. It is proved by a commitment to continuously improve the services quality in terms of tourist attraction, tourist facilities and infrastructure as well as road accessibility and online information. In order to improve the service quality to tourists, Dewi Pule management should know the tourists' satisfaction level. It is important to evaluate the performance of the management and to know the expectations of the visitors. Meggison in Mangkunegara (2005) describes the term performance evaluation as a process used by leaders to assess the target work achieved by employees in accordance with their duties and responsibilities. Simanjuntak (2005) considers that performance evaluation is an assessment of the individual duty implementations, work groups, organizations, or companies. The results of tourists' satisfaction level can be used as a reference to improve service quality (Alegre \& Cladera, 2009; Prayag, 2009; Weaver, Weber, McCleary, 2007). Based on the description above, the research objectives are to determine the tourist satisfaction level and the performance of attractions, accessibility, and amenities in PTV. The results of this study can be used as an evaluation for management to improve the quality of services to meet tourist expectations.

\section{Methodology}

This study uses both qualitative and quantitative (mixed method). According to Sugiyono (2010), the mixed method research combines two research methods at the same time, qualitative and quantitative in a research activity, so that the obtained data can be more comprehensive, valid, reliable, and objective. This study measures tourist satisfaction with 3As components (Attractions, Accessibility, and Amenities) which at the same time become the research variable.

The population in this study was tourists who visited PTV during the period of August to September 2018. Purposive Sampling method was used in this study. The sample was 100 tourists who bought packages through the tourism village secretariat and were able to answer 
questionnaires. Sequential mixed methods strategy was used in this study. The data was collected by distributing questionnaires to tourists in PTV. Interviews were conducted with managers who really understand the ins and outs of tourism village management so far. In addition, field observations were also carried out for supporting the data. Gradual quantitative-qualitative data analysis is used as a technique to analyze the data. It means that the analysis is carried out on quantitative data and then followed by qualitative data analysis. The first analysis was carried out by measuring the tourist satisfaction level using a Likert Scale.

Table 1. The Interpretation of Tourist Satisfaction Scores in PTV

\begin{tabular}{ll}
\hline \multicolumn{1}{c}{ Index Score Range } & \multicolumn{1}{c}{ Interpretation } \\
\hline $0-19.99 \%$ & Not satisfied \\
\hline $20-39.99 \%$ & Less satisfied \\
\hline $40-59.99 \%$ & Quite satisfied \\
\hline $60-79.99 \%$ & Satisfied \\
\hline $80-100 \%$ & Very satisfied \\
\hline
\end{tabular}

(Source: Adaptation of Likert Scale, 2019)

The second is using the Importance Performance Analysis (IPA) which aimed to display information relating to indicators of research variables that influence tourist satisfaction in the form of a Cartesian diagram. Furthermore, qualitative analysis was carried out after the interview and observation process. Qualitative analysis shows the alleged relationship between one fact and the other based on empirical data from the field.

\section{Results and Discussion}

The questionnaire filling results showed some characteristics of respondents, that is gender, age, occupation, and length of stay. It was found that most of the respondents were female in the age group of 46-64 years. Most of the respondents were students both from schools and collage. The respondents' length of stay was mostly above 8 to 24 hours.

Table 2. Respondents' Demographic

\begin{tabular}{|c|c|c|c|}
\hline & \multirow{2}{*}{$\begin{array}{c}\text { Distribution of } \\
\text { Respondents }\end{array}$} & \multicolumn{2}{|c|}{ Total } \\
\hline & & Persons & Percentage \\
\hline \multirow[t]{3}{*}{ Gender } & Male & 41 & $41 \%$ \\
\hline & Female & 59 & $59 \%$ \\
\hline & Total & 100 & 100 \\
\hline \multirow[t]{5}{*}{ Age Group } & $16-25$ & 27 & $27 \%$ \\
\hline & $26-45$ & 27 & $27 \%$ \\
\hline & $46-64$ & 31 & $31 \%$ \\
\hline & $>65$ & 15 & $15 \%$ \\
\hline & Total & 100 & 100 \\
\hline \multirow[t]{4}{*}{ Occupation } & Students & 54 & $54 \%$ \\
\hline & Working & 26 & $26 \%$ \\
\hline & Retirements & 20 & $20 \%$ \\
\hline & Total & 100 & 100 \\
\hline \multirow[t]{4}{*}{ Length of Stay } & 1-8 hours & - & - \\
\hline & $8-24$ hours & 78 & $78 \%$ \\
\hline & $>24$ hours & 22 & $22 \%$ \\
\hline & Total & 100 & 100 \\
\hline
\end{tabular}


Based on the interview, it is said that the segmentation and the main target of the PTV market were school and college students. It also can be seen from the high number of visitors and respondents in that group. Activities that carried out by students in Dewi Pule were usually in the form of orientation and inauguration night and outing classes to improve the quality of group collaboration. Besides that, the second market target comes from the worker segment both from government and private sectors. This can be seen from the number of tourists visiting this group in the second position.

\section{Attraction components}

Based on the Likert scale calculation analysis, the total satisfaction for the Attraction component is $\mathbf{7 1 . 7 \%}$ with interpretation in the Satisfied category. The entire indicators included in the Satisfied category with the river condition as the lowest satisfaction index in $65.6 \%$, while the highest satisfaction index is the indicator of rural natural conditions with 79.6\%. Performance analysis shows that river conditions, tour package prices, cultural attractions, and security and safety in physical activity are the priorities that need to be improved. On the contrary, indicators that needs to be maintained because it has been well implemented by the management, namely the natural conditions and the diversity of activities. Then, the clean and hygiene environment of the village is considered less important by visitors and feels too excessive.

Table 3. Likert Scale Analysis Results On Attraction Components

\begin{tabular}{|c|c|c|c|}
\hline Code & Indicators & $\begin{array}{c}\text { Index } \\
\text { Formula }\end{array}$ & Interpretation \\
\hline A1 & Natural condition & $79.6 \%$ & Satisfied \\
\hline A2 & Clean and hygiene environment & $72.2 \%$ & Satisfied \\
\hline A3 & River conditions & $65.6 \%$ & Satisfied \\
\hline A4 & Tour package price & $71.6 \%$ & Satisfied \\
\hline A5 & $\begin{array}{l}\text { Cultural attractions; dance and art } \\
\text { performances }\end{array}$ & $71.4 \%$ & Satisfied \\
\hline A6 & Diversity of activities & $75.2 \%$ & Satisfied \\
\hline \multirow[t]{2}{*}{ A7 } & Security and safety in physical activity & $66.6 \%$ & Satisfied \\
\hline & AVERAGE & $71.7 \%$ & Satisfied \\
\hline
\end{tabular}

(Source: Researcher's analysis, 2019)

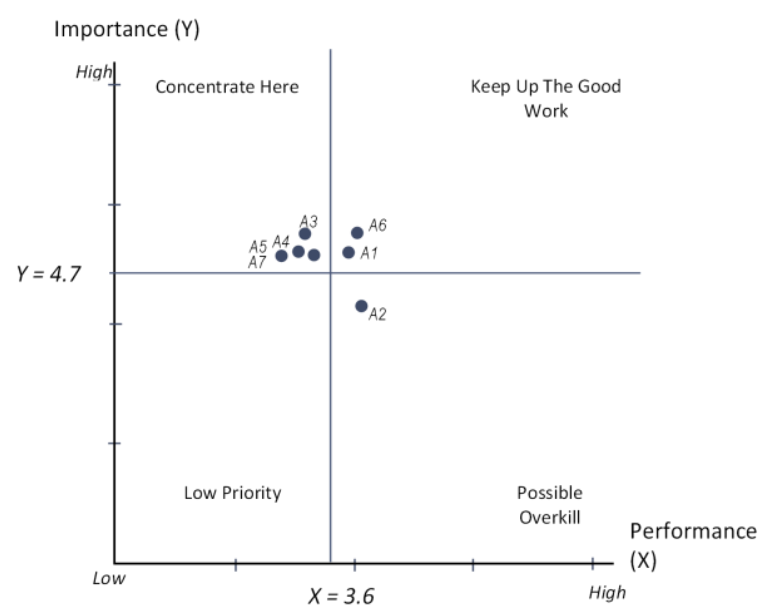

Figure 2. IPA Quadrant for Attraction Component

(Source: Researcher's analysis, 2019) 
The river conditions as one of PTV's attraction had the lowest satisfaction level from tourists due to seasonal factor. In August to September was the dry season in Sleman so the river water level decreases. Furthermore, this condition leads to increasing water turbidity due to tourist activities on the river, and rocks in the river appear on the surface with slippery conditions that endanger visitors. The cultural attractions were also important things that need to be improved because many tourists did not know much about the cultural tourism packages. Cultural packages were usually ordered by government organizations or institutions for formal ceremony of honorary guests. Cultural tourism packages were indeed quite expensive when compared to outbound, fun games and homestay tour packages.

Dewi Pule showed a low percentage of satisfaction in security and safety indicator. It is shown in the second lowest Likert scale and became a priority to be improved refer to the results of IPA. Based on the observation process, the access to the river was quite slippery and there were no handles or supports on the stairs. This condition is alarming for most female respondents aged over 46 who need help and more attention in such activity. According to the PTV management information, they realized that the security system is an important aspect, which is why they have security offices, insurance and first aid kits in case of emergency. However, the technical implementation in the field says the otherwise.

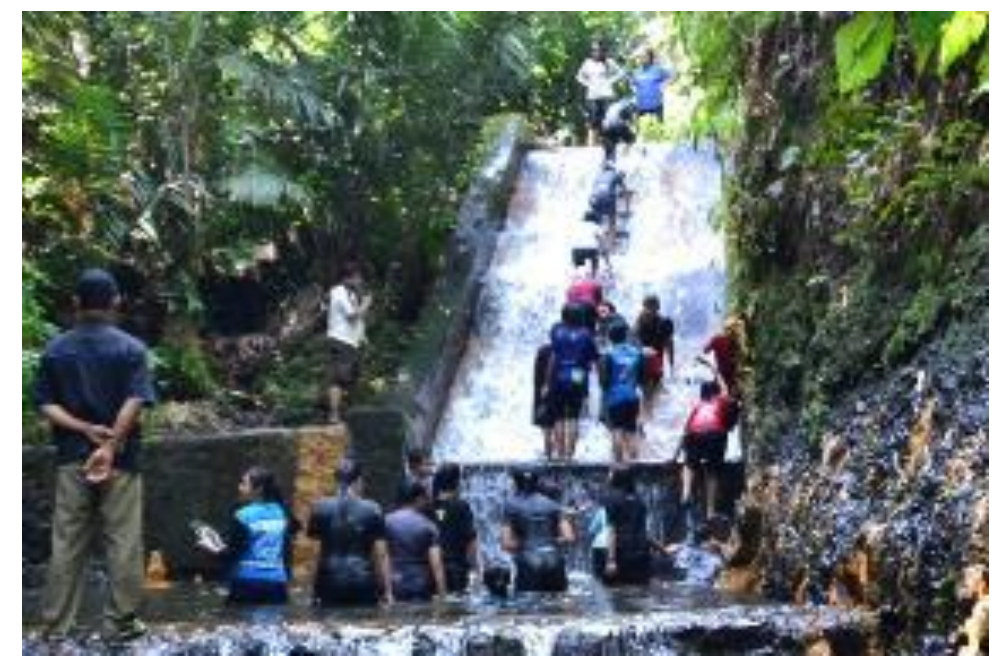

Figure 3. Lack of Safety Equipment in River Trekking Activity

(Source: Researcher's documentation, 2019)

\section{Accessibility component}

Tourist satisfaction with accessibility components shows a Satisfied interpretation on the Likert scale. The road to PTV has the highest score from the respondents and this result is confirmed by IPA, which is to keep up the good work. The PTV's online information has the lowest score on the Likert scale. Even so, this indicator interpreted in Satisfied category. Based on the performance analysis, the indicator of information access in the internet needed to be improved to meet tourist expectations. 
Table 4. Likert Scale Analysis Results for Accessibility Component

\begin{tabular}{clcl}
\hline \multirow{2}{*}{ Code } & \multicolumn{1}{c}{ Indicators } & $\begin{array}{c}\text { Index } \\
\text { Formula }\end{array}$ & Interpretation \\
\hline B1 & The road to Pulesari & $71.6 \%$ & Satisfied \\
\hline B2 & Street sign/signboard to Pulesari & $70.4 \%$ & Satisfied \\
\hline B3 & Road condition in Pulesari & $72 \%$ & Satisfied \\
\hline B4 & Signboard inside Pulesari & $70.4 \%$ & Satisfied \\
\hline B5 & Information access in internet to Pulesari & $67 \%$ & Satisfied \\
\hline & AVERAGE & $70.3 \%$ & Satisfied \\
\hline
\end{tabular}

(Source: Researcher's analysis, 2019)

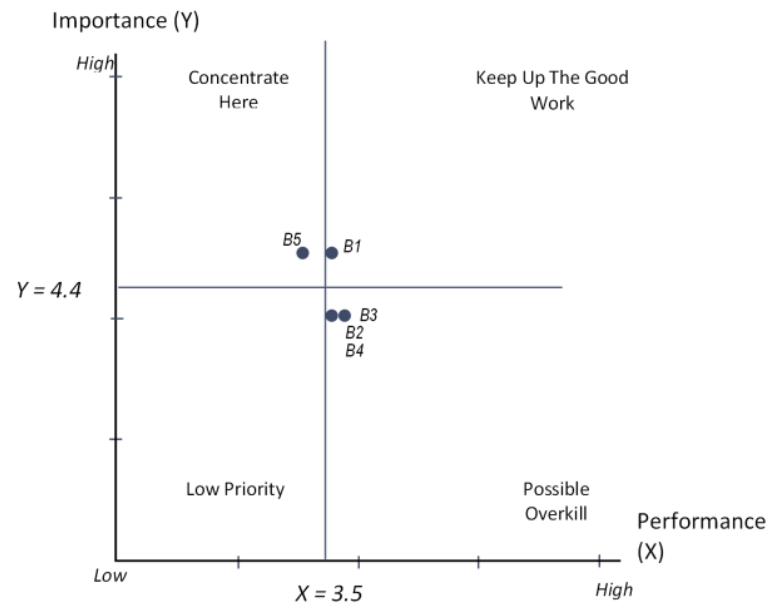

Figure 4. IPA Quadrant for Accessibility Component

(Source: Researcher's analysis, 2019)

Based on the observation, the road condition to PTV has been paved and could be passed by all modes of land transportation both large and small. Moreover, it is easy to find the street sign and direction for tourist to PTV. The indicator that needs to be improved is the ease of information in the internet. From the interview with management, it is found that they use printed media till 2017, such as magazines, daily newspapers, proposals, brochures, and flyers. PTV start using contemporary social media to widen their market segmentation. Even though they already have social media from various platforms, it seemed that the content still lacks information related to PTV and its facilities or services.

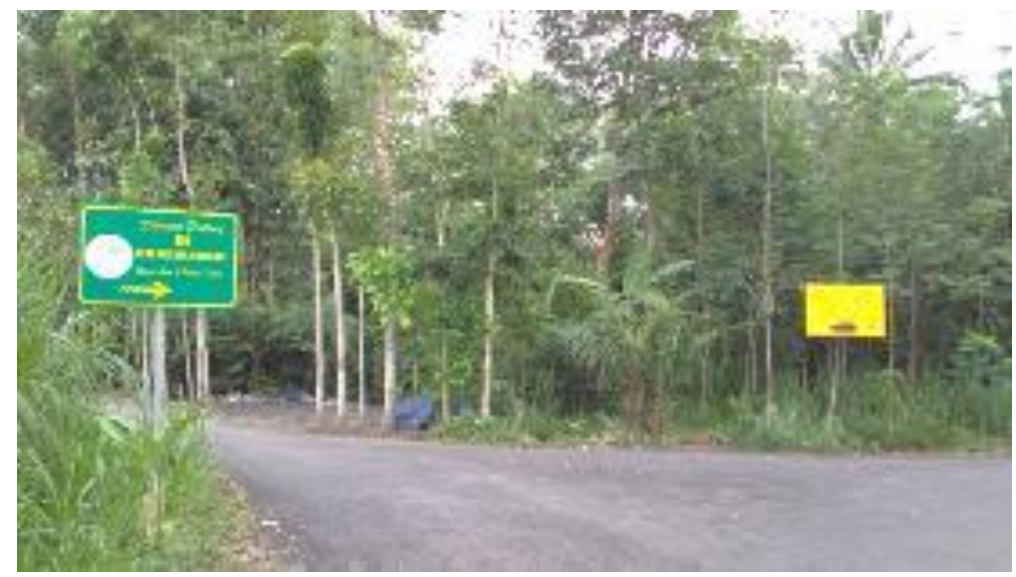

Figure 5. Paved Road and Street Sign to Pulesari Tourism Village

(Source: Researcher's documentation, 2019) 


\section{Amenities component}

The amenities component found in PTV is considered satisfied by tourists. This component has the lowest Likert score among accessibility and attractions components. The highest indicator of amenities is the hospitality of the hosts. The lowest indicator is the souvenirs diversity and packaging. Management needs to improve the quality of local souvenirs which include prices and packaging. The indicators that need to be maintained include the room and toilet cleanliness.

Table 5. Likert Scale Analysis Results for Amenities Component

\begin{tabular}{|c|c|c|c|}
\hline Code & Indicators & $\begin{array}{c}\text { Index } \\
\text { Formula }\end{array}$ & Interpretation \\
\hline $\mathrm{C} 1$ & Room cleanliness & $67.2 \%$ & Satisfied \\
\hline $\mathrm{C} 2$ & Toilet cleanliness & $66.2 \%$ & Satisfied \\
\hline $\mathrm{C} 3$ & Host friendliness & $69.6 \%$ & Satisfied \\
\hline $\mathrm{C4}$ & Homestay facilities & $63.4 \%$ & Satisfied \\
\hline $\mathrm{C} 5$ & Homestay price & $63.4 \%$ & Satisfied \\
\hline C6 & Local souvenirs product & $63.2 \%$ & Satisfied \\
\hline $\mathrm{C7}$ & Souvenirs diversity & $60.6 \%$ & Satisfied \\
\hline $\mathrm{C} 8$ & Souvenirs prices & $61.4 \%$ & Satisfied \\
\hline \multirow[t]{2}{*}{$\mathrm{C9}$} & Souvenirs packaging & $60.6 \%$ & Satisfied \\
\hline & AVERAGE & $64 \%$ & Satisfied \\
\hline
\end{tabular}

(Source: Researcher's analysis, 2019)

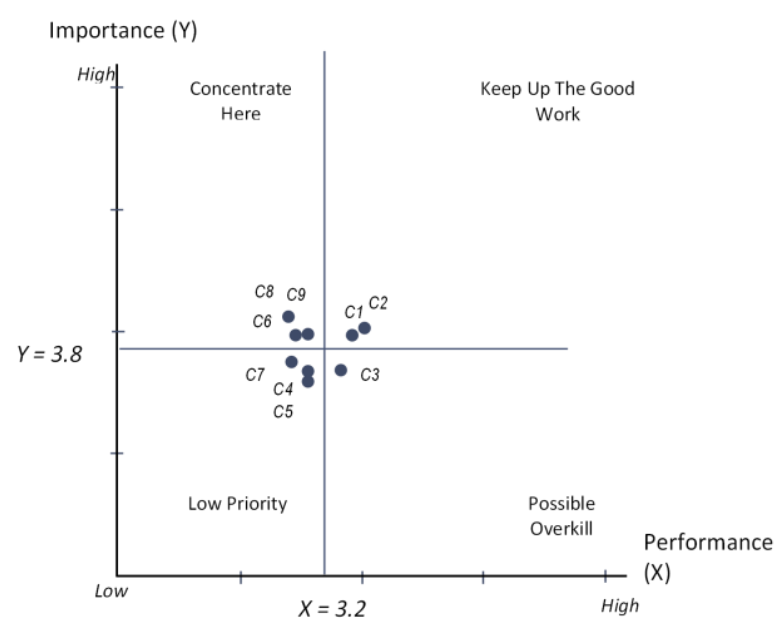

Figure 6. IPA Quadrant for Amenities Component

(Source: Researcher's analysis, 2019)

The amenities found in PTV are homestays and souvenirs. There are 39 homestays with standard facilities including toilet, bed, blanket, pillow, and wardrobe. The cleanliness of the room and toilet was very well cared for by the host. That is because homestays are technically part of the homes of residents whose rooms are rented, so the hosts also benefit from the cleanliness of their homes. Stay travelers show satisfaction with homestay cleanliness, so the management should maintain this condition. The satisfaction with accommodation is largely determined by facilities, cleanliness, and comfort. 
Host friendliness exceeds tourist expectations. They consider the host to be very friendly in serving guests and have the highest level of satisfaction among other indicators. Homestay owners are local residents who are generally thick with Javanese culture that is known to be friendly. In the context of the service industry, friendly attitude is an important element of the product even though it is intangible (Spillane, 1994).

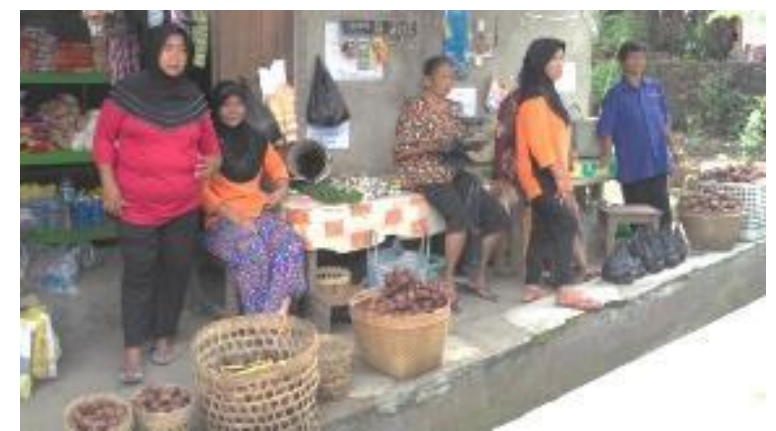

Figure 7. The thorny palm seller as one of souvenirs in PTV.

Unlike the homestay, tourists judge that all souvenir indicators need to be improved. In general, the souvenirs in Turi District were dominated by processed thorny palm and handicraft products. Therefore, the tourists saw that souvenirs diversity in PTV lack of innovation and creation. This is quite reasonable because thorny palm is the biggest potential product in this region. The processed thorny palm products have not been widely known by tourists because there was no show room center for souvenirs in PTV. Most tourists only bought thorny palm in the residents who sold it along the village road. Actually, PTV has various kinds of processed thorny palm with attractive packaging, but its production only at certain events or orders. There were no fixed prices for thorny palm, it depended on the season. It was also a problem that needs to fix by the management because the price of souvenirs or food products in tourist destinations is one of the determinants of the satisfaction level of visiting tourists.

\section{Conclusion}

Market segmentation in Pulesari Tourism Village comes from students and workers with the majority being female. Tour packages purchased by tourists are mostly related to outbound physical activity, river flow, and overnight stays at homestays. Tourists who visit expressed satisfaction with the attractions, accessibility, and amenities found in Pulesari Tourism Village. The performance of attraction components needs to get the largest portion to be improved by the management to meet the tourist's expectations.

Based on this study, the results show that the quality of the 3As component influences the level of satisfaction of visiting tourists. The three components become unity and support each other. A low assessment of one component can be improved by other components that are perceived to have better quality. Even so, the manager still needs to correct the deficiencies. Further research can be done to see whether gender differences have an influence in assessing the components of tourist destinations. This is interesting to study because tourist villages have rural conditions with all their attributes and offer tourist attractions that are closely related to the involvement of physical activities. 
The use of the mixed method in this study can provide research answers from diverse perspectives. The perceived strength is that the presentation of quantitative analysis supported by qualitative analysis can describe in detail the data obtained in the field so as to strengthen the arguments presented. The disadvantage in this study is that it requires a longer time to retrieve data.

\section{References}

Alegre J, Cladera M. Analysing the effect of satisfaction and previous visits on tourist intentions to return. European Journal of Marketing. 2009 May 29;43(5/6):670-85.

Alegre J, Garau J. Tourist satisfaction and dissatisfaction. Annals of tourism research. 2010 Jan 1;37(1):52-73.

Basiya R, Rozak HA. Kualitas Dayatarik Wisata, Kepuasan Dan Niat Kunjungan Kembali Wisatawan Mancanegara Di Jawa Tengah. Jurnal IImiah Dinamika Kepariwisataan. 2012;11(2).

Bodlender J, Lickorish $\amalg$, Jefferson A, Jenkins C. Developing tourism destinations: Policies and perspectives. Harlow: Longman; 1991.

Budiono GL. Kepuasan wisatawan terhadap kualitas pelayanan obyek wisata Gunung Bromo. Jurnal Model Manajemen. 2004;2(1):60-4.

Bursan R. Analisis Pengaruh Dimensi Wisata terhadap Loyalitas Wisatawan (Studi Kasus di Provinsi Lampung). Jurnal Bisnis dan Manajemen. 2006 Sep;3(1):1-3.

Do Valle PO, Silva JA, Mendes J, Guerreiro M. Tourist satisfaction and destination loyalty intention: a structural and categorical analysis. International Journal of Business Science \& Applied Management (IJBSAM). 2006;1(1):25-44.

González ME, Comesaña LR, Brea JA. Assessing tourist behavioral intentions through perceived service quality and customer satisfaction. Journal of business research. 2007 Feb 1;60(2):153-60.

Hermawan H. Pengaruh Daya Tarik Wisata, Keselamatan, Dan Sarana Wisata Terhadap Kepuasan Serta Dampaknya Terhadap Loyalitas Wisatawan: Studi Community Based Tourism Di Gunung Api Purba Nglanggeran. JURNAL MEDIA WISATA: Wahana Informasi Pariwisata. 2017;15(1).

Kalebos F. Faktor-faktor yang mempengaruhi kepuasan wisatawan yang berkunjung ke Daerah Wisata Kepulauan. Jurnal Riset Bisnis dan Manajemen. 2016 Jul 20;4(3).

Kottler P, Keller KL. Marketing management. Analyse, Planung, Umsetzung und. 2006.

Kozak M, Rimmington M. Tourist satisfaction with Mallorca, Spain, as an off-season holiday destination. Journal of travel research. 2000 Feb;38(3):260-9.

Kozak M. Comparative assessment of tourist satisfaction with destinations across two nationalities. Tourism Management. 2001 Aug 1;22(4):391-401.

Laws E. Tourist destination management: issues, analysis and policies. Routledge; 1995.

Mangkunegara AAP. Evaluasi kinerja SDM. Tiga Serangkai; 2005.

Meng F, Tepanon Y, Uysal M. Measuring tourist satisfaction by attribute and motivation: The case of a nature-based resort. Journal of vacation marketing. 2008 Jan;14(1):41-56.

Middleton VT, Fyall A, Morgan M, Morgan M and Ranchhod A. Marketing in travel and tourism. Routledge; 2009.

Nasution S, Nasution MA, Damanik J. Persepsi Wisatawan Mancanegara Terhadap Kualitas Objek dan Daya Tarik Wisata (ODTW) Sumatera Utara. Jurnal Studi Pembangunan. 2005 Oktober, 1(1): 81-96. 
Nuryanti W. Concept, Perspective and Challenges, makalah bagian dari Laporan Konferensi Internasional mengenai Pariwisata Budaya. Yogyakarta: Gadjah Mada University Press. Hal. 1993:2-3.

Oktaviani RW, Suryana RN. Analisis kepuasan pengunjung dan pengembangan fasilitas wisata agro (Studi kasus di Kebun Wisata Pasirmukti, Bogor). Jurnal Agro Ekonomi. 2016 Sep 23;24(1):41-58.

Prayag G. Tourists' evaluations of destination image, satisfaction, and future behavioral intentions - the case of mauritius. Journal of Travel \& Tourism Marketing. 2009 Dec 1;26(8):836-53.

Simanjuntak PJ. Manajemen dan evaluasi kerja. Lembaga Penerbit FEUI, Jakarta. 2005.

Spillane JJ. Pariwisata Indonesia: siasat ekonomi dan rekayasa kebudayaan. Kanisius; 1994.

Sugiyono P. Dr. 2010. Metode Penelitian Kuantitatif, Kualitatif, dan R\&D. Bandung: CV Alfabeta.

Sulistiyana RT. Pengaruh fasilitas wisata dan harga terhadap kepuasan konsumen (Studi pada Museum Satwa). Jurnal Administrasi Bisnis. 2015 Aug 28;25(2).

Sulistiyani E. Membangun Loyalitas Wisatawan Melalui Peningkatan Kualitas Obyek Wisata, Promosi dan Kepuasan Wisatawan di Kawasan Wisata Tawangmangu Karanganyar. Journal Publish. www. polines. ac. id/ragam/indexfiles/jurnalragam/paper7. com. Diakses tanggal. 2010 Dec; 20.

Sunarto. Perilaku konsumen. Yogyakarta: AMUS. 2003.

Suwantoro G. Dasar-dasar pariwisata. Yogyakarta: Andi. 1997.

Taufiq A. Dinamika Pemasaran: Jelajahi dan Rasakan. Jakarta. PT Raja Grafindo Persada. 2005.

Wang Y. More important than ever: Measuring tourist satisfaction. Griffith Institute for Tourism, Griffith University; 2016 Jun.

Weaver PA, Weber K, McCleary KW. Destination evaluation: The role of previous travel experience and trip characteristics. Journal of Travel research. 2007 Feb;45(3):33344. 